AGH DRILLING, OIL, GAS • Vol. 33 • No. $1 \cdot 2016$

http://dx.doi.org/10.7494/drill.2016.33.1.195

\author{
Martin Klempa*, Robert Rado**, Petr Bujok*, \\ Nikola Janečková*, Michal Porzer*
}

\title{
UTILIZATION OF HIGH POTENTIAL GEOTHERMAL ENERGY IN THE CZECH REPUBLIC***
}

\section{INTRODUCTION}

The attempts at using geothermal energy of the earth are associated with the development of renewable energy projects. The basic assumption of technological use of geothermal energy of the rock is the existence of thermal energy, which can be harnessed with the use of special technologies and directly used for space heating or, e.g. transformed into electrical energy (Fig. 1).

Generally, the schematic of industrial use of geothermal energy lies in carrying geothermal heat to the earth surface with the use of a medium/carrier, most frequently water. At least one well is used for this purpose, though in practice usually more wells are employed. Part of the geothermal wells are used for pumping the heated carrier from the underground heat exchanger, whereas the remaining ones are used for its reinjection [7]. Heat recuperated through geothermal wells is used for the heating purposes or, after applying specialist technology, for electricity generation.

* VŠB-Technical University of Ostrava; Faculty of Mining and Geology, 17. listopadu 15, CZ70833 Ostrava Poruba Czech Republic

** AGH University of Science and Technology, Faculty of Drilling, Oil and Gas, Krakow, Poland

*** This article was written in connection with project Institute of clean technologies for mining and utilization of raw materials for energy use - Sustainability program. Identification code: LO1406. Project is supported by the National Program for Sustainability I (2013-2020) and financed by the state budget of the Czech Republic.

This article was written in connection with research project WWNiG BS No. 11.11.190.555 


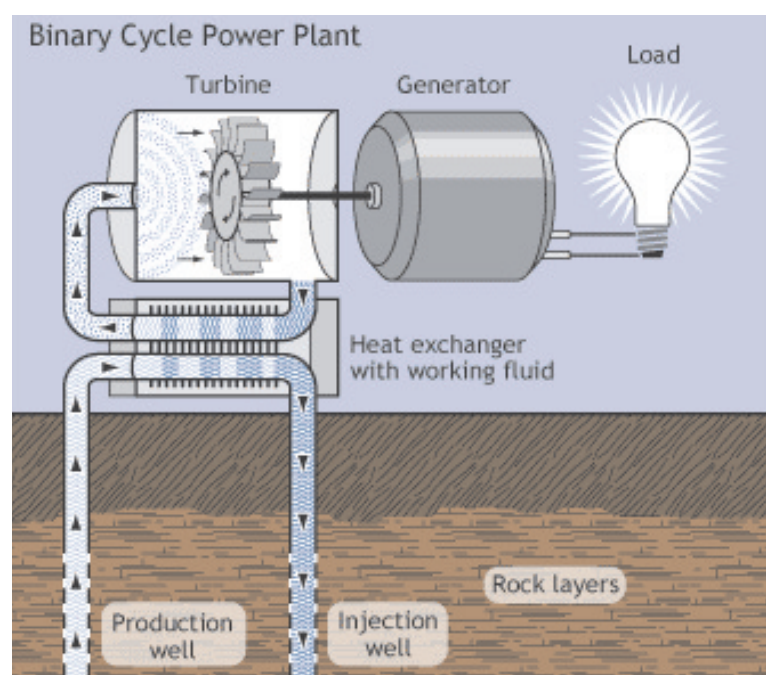

Fig. 1. Schematic of geothermal installation for electricity generation

\section{GEOTHERMAL PROSPECTING AND PRODUCTION}

The development of geothermal energy in the World for heating and electricity generation purposes and the associated development of research methods, dates back to the 1970s. At that time the research in Europe concentrated on hydrothermal systems, except for the Rosemanowes project (UK).

The major phase of the project realized in Rosemanowes, Cornwall took place in 1980-1983 when two wells were drilled to a depth of $2000 \mathrm{~m}$. The rock mass between them was enhanced by injection of a carrier to create a geothermal heat reservoir. However, the system acted differently than assumed. The losses of transporting fluid were too big and the marker tests showed that hydraulic connections between wells were insufficient. In 1991 the project was terminated.

The next project was a European HDR project in Soultz-sous-Foręts, France. It started in 1986 when the first scheduled well GPK1 as drilled to a depth of about $2000 \mathrm{~m}$. Then the well was deepened to $3600 \mathrm{~m}$, and the successive geothermal well GPK2 was drilled to $3800 \mathrm{~m}$. The first geothermal reservoir was performed in this depth interval. In the years 1999-2004 the successive wells were drilled, i.e. GPK3 and GPK4 to a depth of $5000 \mathrm{~m}$; also GPK2 well was deepened to this depth. The second reservoir was made at the depth of 5 kilometers, where GPK2 and GPK4 wells were production (pumping) wells and GPK3 well was an injection well. Finally a geothermal electrical power plant of 1.5 MW was implemented in 2008.

The attempts at using geothermal energy from DHR reservoirs were continued in Basel, Switzerland. Unfortunately, the works had to be stopped because of the geological build of the potential reservoir. From among all European countries, the most 
involved in the development of HDR in this type of projects was Germany. Among the most important were projects localized in Schoenebeck in the Rhine Trough area. The most influential World's geothermal projects based on HDR method have been presented in Figure 2.

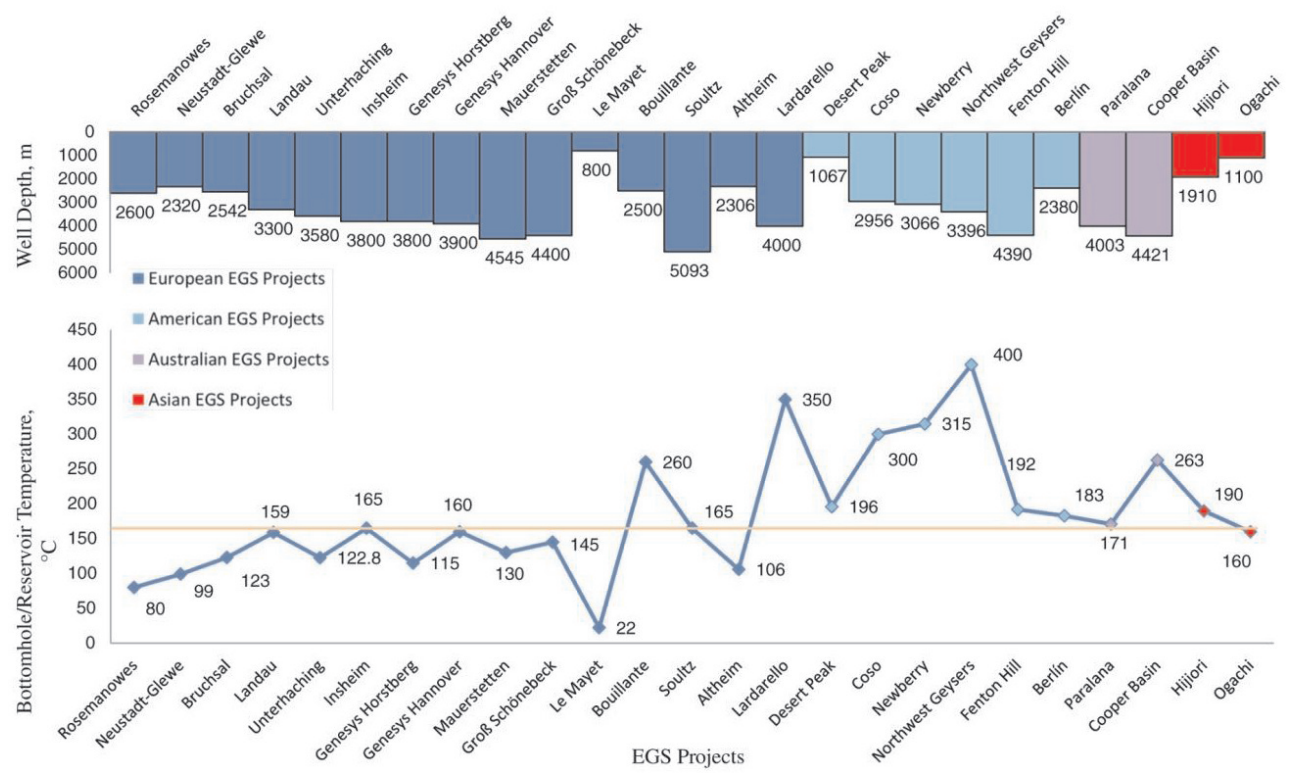

Fig. 2. World's EGS geothermal projects. Upper graph shows the maximum depth of a well, the lower graph illustrates the maximum registered temperature of the reservoir [1]

\section{TYPES OF GEOTHERMAL SYSTEMS \\ IN THE CONTEXT OF GEOLOGICAL CONDITIONS OF THE CZECH REPUBLIC}

In the case of geothermal energy use on industrial scale, the most important feature of geothermal heat is its maximum temperature in the place where heat is recuperated, and the industrial applicability of the produced energy. For practical reasons, geothermal systems can be divided in a number of ways.

Temperature in view, the geothermal systems can be divided into $[2,6]$ :

- high-temperature (hyper-thermal) over $150^{\circ} \mathrm{C}$, can be used for direct electrical energy production with the use of steam turbines;

- medium-temperature $100-150^{\circ} \mathrm{C}$, to a limited extent they can be applied for electrical energy generation with the use of special media, which will power the turbine; can be used for heating purposes;

- low-temperature (below $100^{\circ} \mathrm{C}$ ), mainly used for heating purposes. 
From the geological point of view the systems in the Czech Republic can be divided into:

- hot dry rock (HDR) geothermal systems (geothermal systems in non-hydrated rock mass (HDR));

- geothermal systems in hydrated rock mass;

- heat sources accumulated in deep-seated groundwater.

This paper focuses on the first system, i.e. hot dry rock system.

\section{GEOTHERMAL SYSTEMS IN NON-HYDRATED ROCK MASS (HDR)}

Geothermal systems in non-hydrated rock mass make use of heat energy accumulated in the rock mass. Such systems can be additionally divided according to the presence or absence of cracking networks in the neighborhood of the geothermal system into [4]:

- systems in monolithic hot dry rock (HDR),

- systems in fractured hot rock (FHR),

- enhanced geothermal systems (EGS) - when the underground heat exchanger is stimulated to increase the exchange efficiency.

High-temperature non-hydrated rock is most suitable for industrial use. It can be found at a depth over $5000 \mathrm{~m}$ in the Czech Republic, depending on the region and its geological conditions. They are defined as media with increased heat flow. Their temperature usually ranged between 150 and $200^{\circ} \mathrm{C}$. In such case we have to do with big geothermal energy resources. However their use is limited because of the difficult recuperation. For instance, a liquid medium for energy transport has to be provided [3].

Geothermal energy is recovered by two or more wells, which are localized at a depth interval having highest temperature. If needed, the interval can be additionally fractured to provide a network of communicating cracks. This net of fractures will be used for transporting the medium between wells making up the geothermal system. Then the energy will be recovered in the heat exchange system on the surface.

In the geological conditions of the Czech Republic the use of energy of hot dry rock seems to be most advantageous, which has been proved by research made within the Litomierzyce project, where the residual heat of Earth and heat of the rock are the main sources of heat energy.

The significance of regional fault zones in geothermics can be traced on the example of one of the best geologically analyzed area, i.e. Foreshore Ore Mountains (Fig. 3). The tectonic trough of the Foreshore Ore Mountains covers the Tertiary area of the Chebsky Basin, Sokolov Basin and North Bohemian Basin as well as the Doupov Mountains with the adjacent parts of the Ore Mountains and Slavkovsky Forest to the Czech border. This area is geologically diversified owing to the tectonic processes taking place in the Alpine orogenesis with the successive volcanic activity and weathering of rocks. 


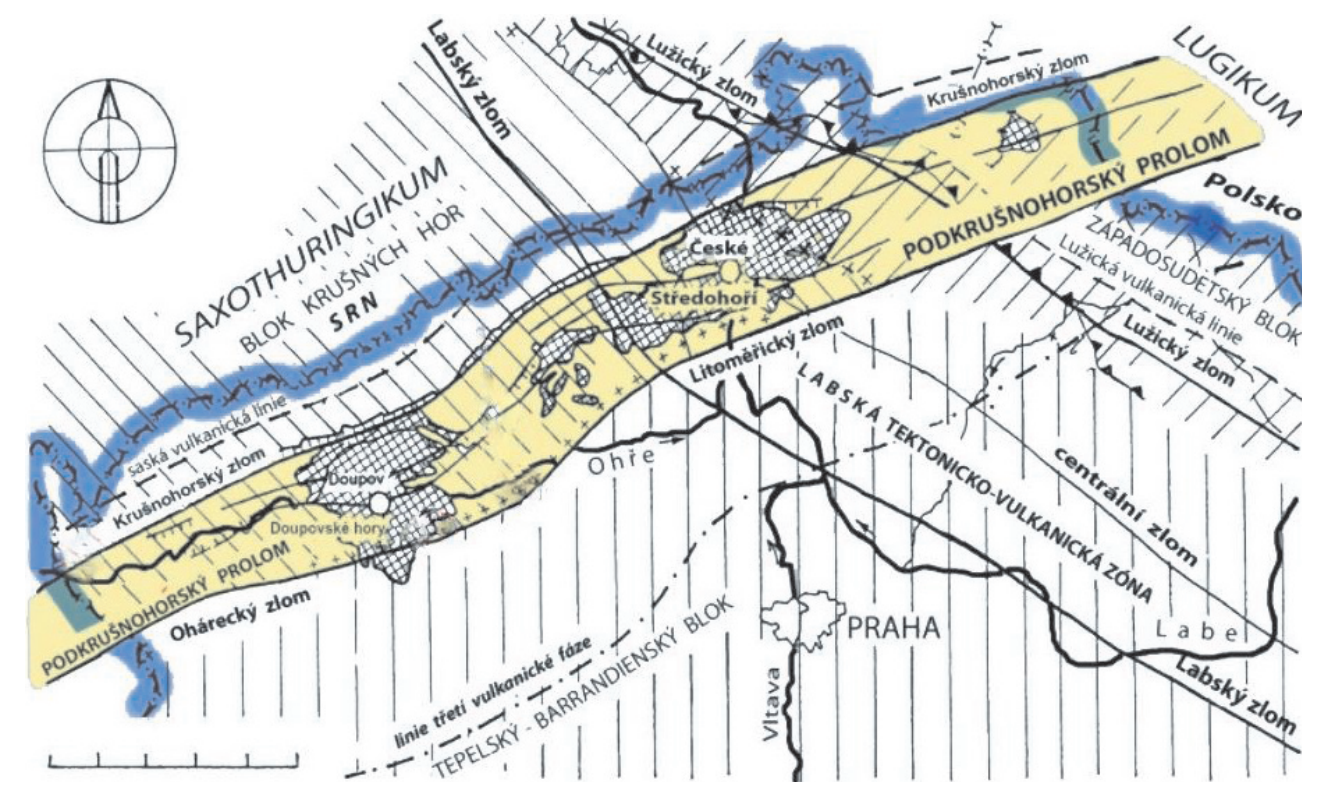

Fig. 3. Schematic of tectonic trough of the Foreshore Ore Mountains with volcanic area (dashed) after [8]

The presence of disturbed geological structures, especially deep faults is an area where heat is moving from the deeper parts of the rock mass. The rift character of the tectonic trough of the Foreshore Ore Mountains is particularly important. In 1972 Lubomir Kopecký described the Ohře rift as a Tertiary zone of the Quaternary and the last tectonic movements of Late Cretaceous, Tertiary and Quaternary basic volcanism and Tertiary and Quaternary sedimentation. It is significantly limited by two faults: Ore Mountains in the north and Litoměřický in the south. The distance between these two faults in the central part is about $25 \mathrm{~km}$. The basement of the rift is covered mainly with sediments of Late Paleozoic, Cretaceous, Tertiary and Quaternary, reaching locally maximum thickness of about $1500 \mathrm{~m}$ and Tertiary volcanism. The sedimentary caprock is considered to be the main thermal insulation, which limits the heat transport during geological evolution of the rock mass. The locally negative gravity anomalies are caused by the build of the basement, which can be explained by the presence of the Hercynian granitoids in the crust.

The most important structure of the tectonic trough of the Foreshore Ore Mountains is a deep Litoměřický fault, which is presently part of the European border between Moldanubicum and Saxothuringicum. Geothermally it is significant that it was rejuvenated several times over the geological history of the Czech Massif. It constitutes sharp boundaries between Phyllites of the late (upper) Proterozoic and Saxothuringian's gneiss blocks. A narrow zone of mica shales, which has its outpit in the Elbe valley, is intercalated with metamorpized incrusted magmatic rocks. In the Upper Paleozoic 
the Litoměřický fault constituted a northern boundary of carbon basins and probably southern boundary of North-Czech Rift.

A project "Analysis of geothermal energy in the Czech Republic" is being prepared for this structure. The participants of the project are: the Faculty of Science Charles University in Prague, VSB-TU Ostrava, the Czech Academy of Science, Czech Geological Survey, Czech Technical University in Prague, Technical University in Liberec and Jan Evangelista Purkyně University in Ústí nad Labem.

The workers of the Faculty of Mining and Geology and Faculty of Civil Engineering VSB-TU Ostrava, Faculty of Drilling, Oil and Gas AGH University of Science and Technology in Kraków, Silesian University of Technology in Gliwice and Technical University of Košice will cooperatively do the research and solve tasks of drilling technology optimization for geothermal wells designing.

\section{MAIN GOAL OF THE RESEARCH PROJECT}

Designing of a geothermal well followed by practical verification of its correctness is important because of the geological and drilling conditions. In the case of drilling at a depth of about $6000 \mathrm{~m}$, extreme conditions appear and may have a negative influence on the material from which the drilling equipment has been made. Owing to the high temperatures and also pressure the presence of fluids and gases will lead to the degrading of the equipment of geothermal wells. Packers, screens, casing and cement stone will be exposed to various factors at various depth, and they will have to be recognized. The recognition is absolutely necessary for planning and carrying laboratory enhancement tests and evaluation of their negative impact on the equipment. Thanks to this the drilling complications can be avoided while drilling and then reconstructing the geothermal wells. The research method's will be worked out in the framework of the program. It will lie in simulating high temperature and pressure conditions in particular depth intervals. The influence of unfavorable wellbore conditions on material degradation (corrosion, loss of material strength, flow beyond pipes) of various types of geothermal rig equipment will be investigated. In this approach the laboratory analyses can be performed on samples on a macro scale.

The purpose of the project is choosing the most appropriate technique of drilling of geothermal wells and optimized drilling process. Drilling is the best way of obtaining information, data and experience for the realization of projects on the production of geothermal energy from deep-seated parts of the rock mass. The wells have to be so designed and equipped as to allow for realization of well tests on the possible use of geothermal energy for the production of electricity and heat. The research will be carried out in deep-seated geological structures and will focus on the geo-mechanics, hydrogeology, hydrodynamics, well geophysics, seismology, geochemistry, mathematical modeling and microbiology. 
Moreover the conceptual works will concentrate on creating underground heat exchangers and optimization of geothermal energy use. Custom Research will be realized at two basic stages of research and realization, i.e. validation of the assumptions.

Apart from above research, the following practical goals will be realized in the project [5]:

- design and verification of geothermal drilling technique;

- design and verification of the design of wells and their equipment;

- work out and optimize fracturing technology;

- design drilling fluids for drilling wells, fracturing, selection of working fluids for the recovery of geothermal energy;

- work out a recipe of cement slurries for sealing casing pipes in high temperature conditions;

- design well tests, as well as research tests and pumping.

One of the first stages will be working out drilling technologies for geothermal wells.

\section{DESIGNING AND VALIDATION OF DRILLING TECHNIQUES AND DESIGN OF GEOTHERMAL WELLS}

The present experience with drilling deep directional wells in the Czech Republic is mainly connected with oil industry. Oil and gaseous wells are almost exclusively drilled in sedimentary strata. The process of drilling a well in sedimentary layers differs from drilling in metamorphic and volcanic rocks, and this type of drilling is typical of geothermal wells. The applied drilling technologies and tools differ in both cases. The conceptual works focus on the design and optimization of the rotary drilling method and applicability of the rotary-percussion method, which is considered to be the most efficient in the case of consolidated rock mass. Moreover the improvement of drilling directional geothermal wells will be postulated in the project.

The selection of appropriate technology of drilling geothermal wells in the Foreshore Ore Mountains is more extensive and refers to the applicability of the drilling technique in the context to the planned depth. In this context the basic problem lies in the fact that the discussed project is both a research and a pilot project, thanks to which the drilling technique will be adjusted to drilling operations at an industrial scale.

The rotary-percussion drilling technology is a solution which should be taken into account. This technique is not new. It has been applied all over the World for drilling in consolidated rocks and is considered to be most efficient. It has been successfully used for drilling of blast holes and research wells in mineral mines mainly with the use of air mud. With the development of technology and equipment and tools it was also adapted for drilling deep wells with the use of foam and liquid muds. The use of this technique to a depth of ca. $500 \mathrm{~m}$ with the use of air or foam mud at normal gradients of reservoir pressure is not a problem. They appear at greater depths where the pressure equilibrium and stability of well's walls have to be controlled. 
With the increasing depth of drilling the flow resistance of muds in the well increases, regardless mud's type. It requires the use of compressors of proper capacity while drilling with the use of air, foam or mud pumps for drilling with classic muds.

At greater depths foam or liquid muds have to be applied. When performing deep drilling, the use of mud of a density, thanks to which the hydrostatic pressure can provide pressure equilibrium in the well, is a must.

These requirements seem to be the only limitations for this drilling technique.

Only a few models of downhole hammers based on clean water as a cleaning medium are offered now. A bigger challenge is the use of downhole hammers with drilling mud as a working medium. In this case the intensive wearing of working elements of the downhole hammer create the problem.

In this case the drilling should be performed with the use of drilling mud. The time of drilling of the hammer on the wellbore bottom, and consequently the number of hoisting operations, will be a serious problem.

Another problem to be solved is the maintenance of the wellbore trajectory. In the case of drilling with the classic method the Bottom Hole Assembly (BHA) can be used or, e.g. Rotary Steerable System (RSS) method. When drilling with the Down the Hole hammer Drilling (DHD) it will be necessary to find a solution which would allow for controlling the course of the wellbore's trajectory.

At present, drilling with DTH techniques reached a depth record of about $3500 \mathrm{~m}$. When taking into consideration this technique, a combined system should be used, i.e. rotary-percussion method to a certain depth, then classic rotary method.

As already mentioned, the drilling area is a result of intensive dynamic processes in the rock mass, and volcanism. The area was subjected to dynamic deformations and metamorphic transformation of rocks. In this situation attention should be paid to the possibility of occurrence of discontinuities of layers and the lack of their succession caused by the lack of dynamics of the processes. This will be a considerable difficulty when drilling and directing the wellbore trajectory.

Geological processes in the Foreshore Ore Mountains area caused that the following elements can be found in the planned geothermal wells: block tectonics, which evoked a decomposition of pre-volcanic basement with various amplitudes of vertical shifts, and severed the area to the fault system, creating rock edges and troughs. Therefore it has to be assumed that drilling wells in that area will not be an easy task.

\section{REFERENCES}

[1] Breede K., Dzebisashvili K., Liu X., Falcone G.: A systematic review of enhanced (or engineered) geothermal systems: past, present and future. Geothermal Energy 2013.

[2] Bujok P., Grycz D., Klempa M., Kunz A., Porzer M., Pytlik A., Rozehnal. Z., Vojčiňak P.: Assessment of the influence of shortening the duration of TRT (thermal response test) on the precision of measured values. Energy, vol. 64, pp. 120-129, published January 2014 DOI 10.1016/j.energy.2013.11.079, ISSN 0360-5442. 
[3] Bujok P., Klempa M., Porzer M., Kunz A., Pospíšil P., Vojčinák P., Sekerášová M.: The utilization of grout source heat pumps (GSHP) for research purpose in the campus of VSB - Technical university of Ostrava. Advances materiál research, vol. 1020, pp. 507-512, TransTech Publications, 2014, Switzerland.

[4] Dobra E., Durove J., Pinka J., Slavkovsky J.: From the Herl'any geyser to prove sources of geothermal potential in the Košice Basin. Acta Montanistica Slovaca, vol. 12, Iss. 1, 2007. ISSN 13351788.

[5] Gonet A., Śliwa T.: Testowanie otworowych wymienników ciepła (TRT). GLOBEnergie, ISSN 1897-1288, nr 1.

[6] Mixa P., Holeček J., Burda J., Bílý P., Novák P., Semíková H.: Metodika stanovení podmínek ochrany při využívání tepelné energie zemské kưry (GEOTERMAL). Technologická agentura České republiky, č. p.: TB030MZPO24, březen 2015.

[7] Śliwa T., Gonet A., Złotkowski A., Sapińska-Śliwa A., Pająk L., Jezuit Z.: Zintegrowany system otworowych wymienników ciepła i kolektorów słonecznych. Monografia, Wydawnictwa AGH, Kraków 2012.

[8] Fejfar O.: Nálezy fosilních savců II. Tuchořice na Lounsku: doklady života v usazeninách třetihorních teplých pramenů. Časopis ŽIVA 2/2011 Nakladatelství Academia Akademie věd ČR. 